Прилози, Одд. мат. тех. науки, МАНУ, XXVII-XXVIII, 1-2 (2006-2007), стр. 93-115

Contributions, Sec. Math. Tech. Sci., MANU, XXVII-XXVIII, 1-2 (2006-2007), pp. 93-115

ISSN 0351-3246

UDC: $2550.348 .436 .098 .3(497.71)$

\title{
EMPIRICAL RELATIONS OF SEISMIC MOMENT AND EARTHQUAKE MOMENT MAGNITUDE TO EARTHQUAKE LOCAL MAGNITUDE FOR THE VARDAR AND WEST MACEDONIA SEISMIC ZONES
}

\author{
Vera Čejkovska
}

\begin{abstract}
A b s t r a c t: Seismic moments $\left(M_{0}\right)$ of 79 earthquakes which ed in the Vardar and West Macedonia seismic zones on the territory of the Republic of Macedonia and neighbouring regions within the period 1992-2002 were obtained by inversion of the amplitude spectra of the vertical components of the short-period shear $S_{g}$ and $L_{g}$ surface waves, digitally recorded on the electromagnetic short-period SS-1 and wide-range WR-1 Kinemetrics seismometers at the stations in Skopje (SKO), Ohrid (OHR), Valandovo (VAY), Bitola (BIA) and Kriva Palanka (KPJ). The inversion was done on the Brune dislocation source model and a proper model of the medium. The data used included earthquake local magnitudes $\left(M_{L}\right)$ between 1.5 and 5.2, for the Vardar seismic zone, and between 1.4 and 5.2, for the West Macedonia seismic zone. Moment magnitudes $\left(M_{W}\right)$ of the earthquakes were calculated using the Kanamori formula. Empirical $M_{0}-M_{L}$ and $M_{W}-M_{L}$ relations were obtained, the first of the kind for seismic zones in the territory of the Republic of Macedonia. The results also appointed to a differentiation between classes of small and middle-sized earthquakes at $M_{L}=5.2$ and to a change in the scaling law of the small earthquakes at $M_{L} \approx 3.0-3.5$ or $M_{0} \approx 6 \cdot 10^{13}-1.5 \cdot 10^{14} \mathrm{~N} \cdot \mathrm{m}$.
\end{abstract}

Key words: seismic source parameters; seismic moment; earthquake moment magnitude; empirical relations 


\section{INTRODUCTION}

\section{A review on seismic moment and purposes of this study}

In the earthquake mechanics studies, the sudden faulting has been approved as the most probable physical model for seismic sources [e.g. 1, 2].

The general solution for the corresponding displacement field can be obtained only by use of the dislocation theory. When specified for far field $(F)$, the amplitude spectrum of that solution has a level in the low-frequency part. For the special case of an isotropic medium (as is the Earth for a wide range of seismic wave periods) and a flat surface fault (which is being the most probable physical model for seismic sources in a wide range of seismic source depths), the low-frequency level is given by [e.g. 1, 3, 4]

$$
\Omega_{5}^{F}\left(\vec{r}_{0}, f\right)_{\left|\vec{r}_{0}\right|=R_{H}, f \rightarrow 0}=\frac{M_{0} \cdot f_{\vartheta \varphi}^{F}}{4 \pi \cdot \rho_{0} \cdot v_{0}^{3} \cdot R_{H}} \equiv \Omega_{0} ;
$$

with:

$$
\begin{gathered}
M_{0}=\mu_{0} \cdot \overline{a^{1}} \cdot \Sigma_{L}=C \cdot \Delta \sigma \cdot \Sigma_{L}^{3 / 2}=\mathrm{const} ; \\
R_{H}=1, \rho_{0}=\rho\left(\vec{r}_{0}\right)=\mathrm{const}, v_{0}=v\left(\vec{r}_{0}\right)=\mathrm{const}, \mu_{0}=\mu\left(\vec{r}_{0}\right)=\mathrm{const}, \\
\vec{r}_{0} \in S_{\text {el.s. }},
\end{gathered}
$$

(our notation). Here " $s$ " in subscript stands for "source", $f$ is the wave frequency, $S_{\text {el.s. }}$ is a sphere surrounding the fault in the far-field, having a centre in the earthquake hypocentre $(H)$, unit radius $\left(R_{H}=1\right)$, and interior (say $V_{\text {el.s. }}$ ) that can be approximated by an isotropic homogeneous elastic medium. $\vec{r}_{0}$ stands for the position of the points on $S_{\text {el.s. }} . M_{0}$ is the so called seismic moment. $f_{\vartheta \varphi}^{F}$ is the radiation pattern of the waves generated by the fault surface and observed in the far field ( $\vartheta$ is the angular, $\varphi$ is the azimuth). It depends on the wave type and on the dislocation model used for the fault. $\rho_{0}, v_{0}$ and $\mu_{0}$ are respectively the density, the wave velocity and the shear modulus on $S_{\text {el.s. }}$. and in $V_{\text {el.s. }} . \Sigma_{L}$ is the final fault surface, $\overline{a^{1}}$ is the absolute value of the aver- 
age final dislocation (slip) on $\Sigma_{L}, \Delta \sigma$ is the average final stress drop on $\Sigma_{L}$ (static stress drop) and $C$ is a constant that depends only on the shape of $\Sigma_{L}$.

Being a constant for a specific fault that is defined through the average final fault properties, the seismic moment has been accepted as a measure of seismic source size or earthquake size [e.g. 3, 5-7]. On its base, a new, nonsaturating and so called earthquake moment magnitude has been defined [8]. On the other hand, the constant $\Delta \sigma$ in eq. (1b) for a group of earthquakes denotes their self-similarity, since the proportionality $\Sigma_{L} \sim M_{0}^{2 / 3}$ is valid then [e.g. 3, 8, 9].

Accordingly to (1), when assuming a specific dislocation model of a flat surface fault as a seismic source, the value of the seismic moment for any earthquake can be obtained from the level in the observed far-field displacement amplitude spectrum, after removing from it the recording instruments' response and the influences of the seismic waves' spreading in real medium between the sphere $S_{\text {el.s. }}$ and the Earth's surface. The last can be removed conventionally, on certain models of the medium, or by empirical Green's function deconvolution method, when the whole source displacement amplitude spectrum for the analysed earthquake is obtained directly by division of the instrumentally corrected spectra of that earthquake and an adjacent small earthquake (forshock or aftershock) with same location and source mechanism (means the trace of the small earthquake is treated as Green's function for the medium, i.e. as a response of the medium on an impulse point force).

Following [10 and 5], many occurred strong earthquakes have been separately successfully analysed through the seismic moment. A special interest has been put on global, regional and local empirical relations between the seismic moment and other particular seismic source parameters to earthquake magnitude [e.g. 6-9, 11-22]. On the one hand, the conditions of existence or nonexistence of self-similarity of the earthquakes are determined through those relations, and thus a better understanding of the earthquakes' originating in connection to the geological features and tectonic conditions is secured. On the other hand, those relations are basis for quick routine determination of a particular seismic source parameter only when other seismic source parameter or the earthquake magnitude is known. The both aspects can provide better preconditions for seismic regionalization and hazard assessment.

As known [23], three main neotectonic regions spread on the territory of the Republic of Macedonia, namely, Vardar zone, West Macedonia and East 
Macedonia, which developed within major, regional tectonic units (Fig. 1). These three regions exhibit differences in the seismic activity too, which is taken as an argument to consider them as separate seismic zones [24, 25], bearing the same names.

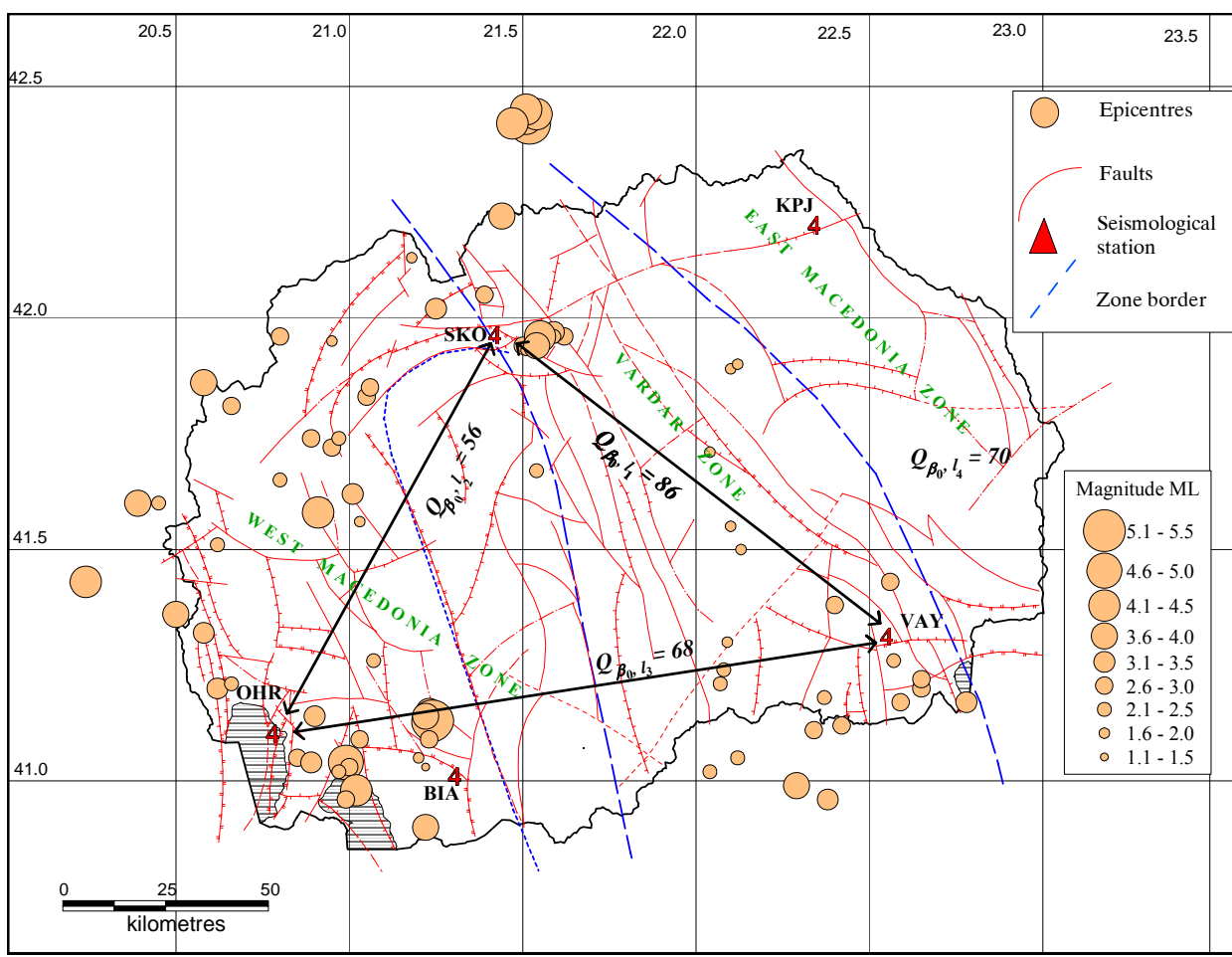

Fig. 1. Neotectonic zones and faults on the territory of the Republic of Macedonia, epicentres and local magnitudes of the earthquakes under study (see Table 2) and used values of the quality factor $Q$

The purpose of this study is to set up empirical relations of the seismic moment and earthquake moment magnitude to the earthquake local magnitude exactly for the seismic zones on the territory of the Republic of Macedonia.

Records from the first decade of digital recording of the stations of the seismological network in the Republic of Macedonia (SORM), that is 19922002 , were used in the study. The maximum observed local magnitude on the 
territory of the Republic of Macedonia and neighbouring areas during that period was 5.2.

Thus the two main conditions of the study, i.e. the use of the seismic records from the same territory where from the earthquakes originated and the size of earthquakes themselves, led to dealing with the methodology of average source parameters determination which should be appropriate for continental earthquakes that are classified as near or local and small to middle-sized.

The widely accepted method for such studies [e.g. 13, 16, 20, 21] uses the spectral displacement amplitude analysis of short-period shear waves of $S_{g}$ type and short-period surface waves of $L_{g}$ type ( $P-S V$ and $S H$ components) or $R_{g}$ type ( $P-S V$ components), since those waves, spreading only in the upper (granite) crustal layer (i.e. having no reflections and refractions on inner discontinuities), transmit the greatest part of the energy of the continental earthquakes all up to epicentral distances of $1000 \mathrm{~km}$. In cases of small near earthquakes, however, the whole trace of shear $(S)$ waves is used [e.g. 19]. Further, only the vertical components of all the waves mentioned are used, since then the coefficient of the free Earth's surface effect has the value 1, and the spectral amplitudes determination is done only from one (vertical) channel of the recording instruments (i.e. errors are minimized). The Brune dislocation model [26 and 27] or its generalization [e.g. 20 and 21] is chosen, since this model had been supported in many near-field and far-field investigations of the earthquakes specified [2].

In this study, seismic moment determinations were done by inverting the amplitude spectra of the vertical components of the observed $S_{g}$ and $L_{g}$ waves, on the Brune dislocation model. One of the main selection criteria for the data was the preferring of source and receiver locations within the same seismic zone. The extracting of the influences of real medium in the observed spectra was done conventionally, using a model for the medium that corresponds to the specific geological, tectonic and seismotectonic characteristics of the territory of the Republic of Macedonia and the data used.

\section{DATA}

Vertical components of the digital records of about 380 earthquakes from the period 1992-2002, with locations within the territory of the Republic of Macedonia and the neighboring areas, were preliminary analysed. The re- 
cords were obtained in the stations in Skopje (SKO), Ohrid (OHR), Valandovo (VAY), Bitola (BIA) and Kriva Palanka (KPJ), on Kinemetrics three channelled short-period SS-1 or wide-band range WR-1 seismometers, with Kinemetrics digital 16-bits SSR recorders working at a sampling rate of $60 \mathrm{~Hz}$ or $100 \mathrm{~Hz}$. The original filtering included low-cut $0.01 \mathrm{~Hz}$ and high-cut $15 \mathrm{~Hz}$ filters.

Since all the elements of the used recording equipment are linear and time-invariant, the final frequency response function $T_{i n s t r .}(f)$ for each channel is given by the product of the corresponding frequency response functions of the elements,

$$
T_{\text {instr. }}(f)=T_{\text {seism. }}(f) \cdot T_{S S R-1}(f) \cdot T_{\text {filter } 1}(f) \cdot T_{\text {filter } 2}(f)
$$

The preliminary data included local magnitudes $\left(M_{l}\right)$ between 1.4 and 5.2 , epicentral distances $(\Delta)$ between 10 and $159.7 \mathrm{~km}$ and hypocentral depths $(h)$ between 4 and $30 \mathrm{~km}$. Accordingly to the scheme of the crust under the Balkan region that has been made in [28] (Table 1), all the analysed earthquakes originated from the upper (granite) crust layer, and thus the first arrival in the $S$ traces on the records was assumed here as $S_{g} . L_{g}$ phase occurrence started at hypocentral distance $R_{H} \approx 80 \mathrm{~km}$. The latter has been being the case with the seismological observations on the territory of the Republic of Macedonia since 1957, and it has to do with a specific distribution of the earthquakes' hypocentres within the granite layer, mostly at depths about $h=1 \mathrm{~km}$.

T a b le 1

The parameters of the crustal model in [28]

\begin{tabular}{|c|c|c|c|c|c|}
\hline \multicolumn{2}{|c|}{$\begin{array}{l}\text { Layer and depths } \\
\text { of the boundary } \\
\text { discontinuities }\end{array}$} & $\begin{array}{c}\text { Average den- } \\
\text { sity } \\
\rho_{0}\end{array}$ & $\begin{array}{l}\text { Average shear } \\
\text { modulus } \\
\mu_{0}\end{array}$ & $\begin{array}{c}P \text {-wave average } \\
\text { phase velocity } \\
\alpha_{0}\end{array}$ & $\begin{array}{c}S \text {-wave average } \\
\text { phase velocity } \\
\beta_{0}\end{array}$ \\
\hline & $\mathrm{km}$ & $10^{3} \mathrm{~kg} / \mathrm{m}$ & $10^{10} \mathrm{~N} / \mathrm{m}^{2}\left(=10^{5}\right.$ bar $)$ & $\mathrm{km} / \mathrm{s}$ & $\mathrm{km} / \mathrm{s}$ \\
\hline \multirow{2}{*}{ Crust } & Granite, $0-30$ & 2.82 & 3.36 & 5.80 & 3.45 \\
\hline & Basalt, $30-40$ & 3.02 & 4.48 & 6.65 & 3.85 \\
\hline Mantle & & 3.33 & 6.89 & 8.00 & 4.55 \\
\hline
\end{tabular}


The first data selection included the following criteria:

- clear onset of the $S_{g}$ phase or well developed $L_{g}$ phase on the record;

- for earthquakes for which only records with $R_{H}<80 \mathrm{~km}$ were available (no $L_{g}$ phase occurred), the next criteria were $M_{L}<2.5$ and $R_{H}>15 \mathrm{~km}$, put in order to provide securely a well defined low-frequency part in $S_{g}$ farfield displacement amplitude spectra;

the source and receiver locations within the same seismic zone were preferred, in order to strictly differ the seismotectonic properties in the different seismic zones.

The further processing was done with the seismological software SEISAN 7.2 [29], after the original SSR digital records had been converted into the SEISAN format. A preliminary amplitude spectral analysis of the selected phases and the corresponding noise was done at first. Additional high-cut filtering at $10 \mathrm{~Hz}$ was used in cases of significant noise. In that way, the final frequency band included in the data was 0.01 to $10 \mathrm{~Hz}$ or 0.01 to $15 \mathrm{~Hz}$. Further, only amplitude spectra with signal-to-noise ratios greater than 4 were chosen for final analysis.

Finally, exactly 85 records for 85 earthquakes were selected, mainly with the preferred locations of the source and the receiver within the same seismic zone. Only six of the selected records were for earthquakes from the East Macedonia seismic zone. Therefore that zone was excluded from the investigation.

From the remained 79 records, 39 refer to 39 earthquakes from the Vardar seismic zone, with local magnitudes $M_{L}$ between 1.5 and 5.2 and epicentral distances $\Delta$ between 34.6 and $159.7 \mathrm{~km}$, and 40 records to 40 earthquakes from the West Macedonia seismic zone, with $M_{L}$ between 1.4 and 5.2 and $\Delta$ between 17.6 and $120.5 \mathrm{~km}$ (Table 2, Fig. 1). The included hypocentral depths $h$ in the both zones are between 4 and $25 \mathrm{~km}$, or average at $h \approx 15 \mathrm{~km}$. The $M_{L}$ values of 5.2 refer to the Bitola earthquake of September 1, 1994, $16 \mathrm{~h} 12 \mathrm{~min}$ UTC (West Macedonia seismic zone, the Republic of Macedonia), and to the Gjilane earthquake of April 22, 2002, $10 \mathrm{~h} 51$ min UTC (Vardar seismic zone, Kosovo region, the Republic of Serbia). 
T a b 1 e 2

List of locations, local magnitudes $\left(M_{L}\right)$ and obtained seismic moments $\left(M_{0}\right)$ and moment magnitudes $\left(M_{W}\right)$ for earthquakes under study, sorted by ascending $M_{L}$ values. Locations and $M_{L}$ values are provided by SORM - Seismological Observatory of the Republic Macedonia

Other symbols: $h$ - hypocentral depth; Stat., spec. - the station which record is used in the spectral analysis, with $\Delta$ as its epicentral distance; $O M$ - low-frequency level of the log-amplitude spectrum of the seismic trace under analysis that is corrected for instrument response and anelashic attenuation

\begin{tabular}{|c|c|c|c|c|c|c|c|c|c|c|c|c|c|}
\hline $\begin{array}{c}\text { Event } \\
\text { No. }\end{array}$ & $\begin{array}{l}\text { Date } \\
\text { d.m.y }\end{array}$ & & $\begin{array}{l}\text { igin } \\
\text { UTC } \\
\text { min }\end{array}$ & $\mathrm{C}$ & $\begin{array}{l}\text { Lat. } \\
\left({ }^{\circ} \mathrm{N}\right)\end{array}$ & $\begin{array}{l}\text { Long. } \\
\left({ }^{\circ} \mathrm{E}\right)\end{array}$ & $\begin{array}{c}h \\
(\mathrm{~km}) \\
\end{array}$ & $M_{L}$ & $\begin{array}{l}\text { Stat., } \\
\text { spec. }\end{array}$ & $\begin{array}{c}\Delta \\
(\mathrm{km})\end{array}$ & $\begin{array}{c}O M \\
(\mathrm{~nm} \cdot \mathrm{s})\end{array}$ & $\begin{array}{c}M_{0} \\
(\mathrm{~N} \cdot \mathrm{m})\end{array}$ & $M_{W}$ \\
\hline \multicolumn{14}{|c|}{ Vardar seismic zone } \\
\hline 1 & 07.07 .1998 & 08 & 36 & 58.9 & 41.89 & 22.10 & 18 & 1.5 & KPJ & 41.6 & 0.9 & $70 \mathrm{E}+11$ & 1.9 \\
\hline 2 & 09.03 .1999 & 07 & 21 & 32.3 & 41.71 & 22.04 & 20 & 1.5 & KPJ & 61.5 & 0.9 & $1.40 \mathrm{E}+12$ & 2.0 \\
\hline 3 & 19.11.1996 & 12 & 35 & 12.3 & 41.50 & 22.13 & 24 & 1.7 & VAY & 41.8 & 1.2 & $2.10 \mathrm{E}+12$ & 2.1 \\
\hline 4 & 06.07 .1998 & 23 & 44 & 28.9 & 41.90 & 22.12 & 15 & 1.7 & KPJ & 39.8 & 1.2 & $1.80 \mathrm{E}+12$ & 2.1 \\
\hline 5 & 14.02.1999 & 08 & 07 & 29.6 & 41.94 & 21.51 & 8 & 1.8 & BIA & 103.4 & 1.1 & $3.10 \mathrm{E}+12$ & 2.3 \\
\hline 6 & 28.03 .1996 & 13 & 22 & 10.6 & 41.30 & 22.09 & 25 & 1.9 & VAY & 40.3 & 1.1 & $1.60 \mathrm{E}+12$ & 2.1 \\
\hline 7 & 20.12 .1996 & 12 & 37 & 01.2 & 41.55 & 22.10 & 19 & 1.9 & VAY & 46.8 & 1.2 & $2.20 \mathrm{E}+12$ & 2.2 \\
\hline 8 & 13.04 & 02 & 09 & 58.3 & 41.93 & 21.51 & 10 & 1.9 & BIA & 102.4 & 1.2 & $3.90 \mathrm{E}+12$ & 2.3 \\
\hline 9 & 17.08 .1999 & 21 & 33 & 32.5 & 41.18 & 22.37 & 4 & 2.0 & BIA & 89.7 & 1.4 & $5.70 \mathrm{E}+12$ & 2.4 \\
\hline 10 & 02.03 .1993 & 14 & 50 & 27.4 & 41.21 & 22.07 & 10 & 2.1 & SKO & 99.7 & 1.6 & $9.60 \mathrm{E}+12$ & 2.6 \\
\hline 11 & 18.08.1992 & 18 & 03 & 17.2 & 41.67 & 21.54 & 19 & 2.2 & SKO & 34.6 & 1.6 & $4.20 \mathrm{E}+12$ & 2.4 \\
\hline 12 & 01.09 & 00 & 41 & 20.2 & 41.26 & 22.57 & 7 & 2.2 & BIA & 108.0 & 1.4 & $6.30 \mathrm{E}+12$ & 2.5 \\
\hline 13 & 14.05 .2000 & 18 & 07 & 02.8 & 41.02 & 22.04 & 12 & 2.2 & BIA & 60.2 & 1.8 & $1.00 \mathrm{E}+13$ & 2.6 \\
\hline 14 & 31.01 .1993 & 04 & 08 & 14.9 & 41.05 & 22.12 & 10 & 2.4 & SKO & 117.1 & 1.5 & $8.20 \mathrm{E}+12$ & 2.6 \\
\hline 15 & 02.03 & 17 & 4 & 20.2 & 41.2 & 22.08 & 16 & 2.3 & SKO & 97.3 & 1.4 & $6.00 \mathrm{E}+12$ & 2.5 \\
\hline 16 & 03.12 .1995 & 12 & 37 & 52.5 & 41.96 & 21.59 & 15 & 2.4 & OHR & 115.1 & 1.3 & $5.20 \mathrm{E}+12$ & 2.4 \\
\hline 17 & 03.01 .1998 & 11 & 13 & 14.2 & 42.05 & 21.39 & 7 & 2.5 & BIA & 114.6 & 1.5 & $8.10 \mathrm{E}+12$ & 2.5 \\
\hline 18 & 26.03 .1998 & 20 & 38 & 01.4 & 41.22 & 22.65 & 12 & 2.5 & BIA & 113.6 & 1.7 & +13 & 2.7 \\
\hline 19 & 04.04 .1998 & 22 & 47 & 48.0 & 41.20 & 22.65 & 12 & 2.5 & BIA & 113.2 & 1.6 & $1.00 \mathrm{E}+13$ & 2.6 \\
\hline 20 & 01.08 .1998 & 18 & 58 & 19.9 & 41.43 & 22.56 & 11 & 2.5 & BIA & 113.3 & 1.5 & $8.10 \mathrm{E}+12$ & 2.5 \\
\hline 21 & 03.12 .1995 & 14 & 35 & 01.1 & 41.96 & 21.62 & 15 & 2.6 & OHR & 116.6 & 1.6 & $1.00 \mathrm{E}+13$ & 2.6 \\
\hline 22 & 02.03 .1996 & 04 & 08 & 18.6 & 41.11 & .34 & 20 & 2.6 & OHR & 129.5 & 1.6 & $1.10 \mathrm{E}+13$ & 6 \\
\hline
\end{tabular}




\begin{tabular}{|c|c|c|c|c|c|c|c|c|c|c|c|c|}
\hline Event & $\begin{array}{l}\text { Date } \\
\text { d.m.y }\end{array}$ & & $\begin{array}{l}\text { igin time: } \\
\text { UTC } \\
\text { min sec }\end{array}$ & $\begin{array}{l}\text { Lat. } \\
\left({ }^{\circ} \mathrm{N}\right)\end{array}$ & $\begin{array}{l}\text { Long. } \\
\left({ }^{\circ} \mathrm{E}\right) \\
\end{array}$ & $\begin{array}{c}h \\
(\mathrm{~km}) \\
\end{array}$ & $M_{L}$ & $\begin{array}{l}\text { Stat., } \\
\text { spec. }\end{array}$ & $(\mathrm{km})$ & $\begin{array}{c}O M \\
(\mathrm{~nm} \cdot \mathrm{s}) \\
\end{array}$ & $\begin{array}{c}M_{0} \\
(\mathrm{~N} \cdot \mathrm{m})\end{array}$ & $M_{W}$ \\
\hline 23 & 09.04 .1 & 04 & 3528.6 & 41.94 & 21.50 & 7 & 2.6 & HR & 109.1 & 1.5 & $7.90 \mathrm{E}+12$ & 2.5 \\
\hline 24 & 09.11 .1996 & 16 & $02 \quad 08.1$ & 41.38 & 22.40 & 6 & 2.6 & BIA & 98.8 & 1.6 & $9.50 \mathrm{E}+12$ & 2.6 \\
\hline 25 & 28.03 .1998 & 18 & 1323.9 & 41.17 & 22.59 & 9 & 2.6 & BIA & 107.7 & 1.6 & $9.90 \mathrm{E}+12$ & 2.6 \\
\hline 26 & 03.02 . & 23 & 1110.2 & 41.12 & 22.42 & 14 & 2.7 & SKO & 125.1 & 1.7 & $40 \mathrm{E}+13$ & 2.7 \\
\hline 27 & 31.03 .1998 & 13 & 1114.0 & 42.02 & 21.25 & 15 & 3.0 & BIA & 111.3 & 2.4 & $6.40 \mathrm{E}+13$ & 3.1 \\
\hline 28 & 05.01 .1993 & 16 & 3656.1 & 41.17 & 22.78 & 6 & 3.1 & SKO & 143.0 & 2.3 & $5.70 \mathrm{E}+13$ & 3.1 \\
\hline 29 & 12.04 .1996 & 05 & 4931.2 & 40.96 & 22.38 & 20 & 3.3 & BIA & 89.1 & 2.6 & $9.10 \mathrm{E}+13$ & 3.2 \\
\hline 30 & 29.09 .1995 & 06 & 5328.5 & 41.97 & 21.59 & 11 & 3.4 & OHR & 116.0 & 2.5 & $8.20 \mathrm{E}+13$ & 3.2 \\
\hline 31 & 15.04 .1999 & 23 & 0254.8 & 41.94 & 21.54 & 3 & 3.6 & BIA & 103.9 & 2.7 & $1.20 \mathrm{E}+14$ & 3.3 \\
\hline 32 & 03.10 .1992 & 18 & 2037.1 & 40.99 & 22.29 & 19 & 3.9 & SKO & 130.2 & 3.0 & $2.80 \mathrm{E}+14$ & 3.6 \\
\hline 33 & 14.06 & 12 & 1200.5 & 2 & 21.44 & 24 & 3.9 & OHR & 134.2 & 3.3 & $5.60 \mathrm{E}+14$ & 3.8 \\
\hline 34 & 13.08 & 22 & $48 \quad 26.6$ & 41.96 & 21.55 & 10 & 4.0 & BIA & 106.2 & 3.3 & $5.00 \mathrm{E}+14$ & 3.7 \\
\hline 35 & 24.04 .2002 & 11 & 2422.2 & 42.43 & 21.51 & 18 & 4.1 & BIA & 157.5 & 3.4 & $7.60 \mathrm{E}+14$ & 3.9 \\
\hline 36 & 24.04 .2002 & 23 & 3757.5 & 42.44 & 21.54 & 20 & 4.1 & BIA & 158.9 & 3.4 & +14 & 3.9 \\
\hline 37 & 25.04 .2002 & 03 & 4334.8 & 42.4 & 2151 & 18 & 4.1 & BIA & 159.7 & 3.4 & $7.70 \mathrm{E}+14$ & 3.9 \\
\hline 38 & 26.04 .2002 & 00 & 2131.7 & 42.42 & 21.47 & 12 & 4.1 & BIA & 156.1 & 3.4 & $7.60 \mathrm{E}+14$ & 3.9 \\
\hline 39 & 24.04 . & 10 & 5151.1 & 42.42 & 21.52 & 15 & 5.2 & BIA & 156.5 & 5.0 & $3.00 \mathrm{E}+16$ & 4.9 \\
\hline \multicolumn{13}{|c|}{ West Macedonia seismic zone } \\
\hline 1 & 2 & 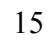 & .5 & 4 & 21.22 & 20 & 1.4 & OHR & 36 & 0.9 & 11 & 1.9 \\
\hline 2 & 19.04 .1996 & 05 & 3736.3 & 41.95 & 20.95 & 18 & 1.7 & SKO & 40.7 & 1.2 & $1.90 \mathrm{E}+12$ & 2.1 \\
\hline 3 & 11.05 .1996 & 08 & 1928.8 & 42.13 & 21.18 & 20 & 1.8 & SKO & 27.7 & 1.4 & $2.30 \mathrm{E}+12$ & 2.2 \\
\hline 4 & 21 & ? & 2 & 4 & 0 & 22 & 1.9 & IR & 34.4 & 1.6 & 12 & 2.4 \\
\hline 5 & 05.02 .2000 & 00 & 3734.1 & 41.56 & 21.03 & 20 & 1.9 & BIA & 64.9 & 1.4 & $4.60 \mathrm{E}+12$ & 2.4 \\
\hline 6 & 05.03 .1996 & 21 & 1549.9 & 41.74 & 20.97 & 17 & 2.0 & SKO & 46.8 & 1.3 & $2.70 \mathrm{E}+12$ & 2.2 \\
\hline 7 & 31.03 . & 19 & 4036.3 & 41.5 & 20.62 & 0 & 2.0 & OHR & 40.1 & 1.2 & $2.00 \mathrm{E}+12$ & 2.1 \\
\hline 8 & 12.06 .1996 & 13 & $02 \quad 14.5$ & 41.02 & 20.97 & 23 & 2.3 & OHR & 17.6 & 1.7 & $3.90 \mathrm{E}+12$ & 2.3 \\
\hline 9 & 14.07. & 07 & 4131.8 & 41.60 & 20.45 & 12 & 2.3 & BIA & 97.6 & 1.9 & $1.90 \mathrm{E}+13$ & 2.8 \\
\hline 10 & 27.01 .1998 & 05 & 3443.3 & 41.26 & 21.07 & 10 & 2.3 & BIA & 34.2 & 2.2 & $1.50 \mathrm{E}+13$ & 2.7 \\
\hline 11 & 13.06 .2000 & 14 & $44 \quad 05.3$ & 65 & 80 & 16 & 2.4 & BIA & 82.7 & 1.9 & $1.80 \mathrm{E}+13$ & 2.8 \\
\hline
\end{tabular}

Прилози, Одд. мат. тех. науки, XXVII-XXVIII, 1-2 (2006-2007), стр. 93-115 


\begin{tabular}{|c|c|c|c|c|c|c|c|c|c|c|c|c|}
\hline $\begin{array}{l}\text { Event } \\
\text { No. }\end{array}$ & $\begin{array}{l}\text { Date } \\
\text { d.m.y }\end{array}$ & & $\begin{array}{l}\text { igin time: } \\
\text { UTC } \\
\text { min sec }\end{array}$ & $\begin{array}{l}\text { Lat. } \\
\left({ }^{\circ} \mathrm{N}\right)\end{array}$ & $\begin{array}{l}\text { Long. } \\
\left({ }^{\circ} \mathrm{E}\right)\end{array}$ & $\begin{array}{c}h \\
(\mathrm{~km})\end{array}$ & $M_{L}$ & $\begin{array}{l}\text { Stat., } \\
\text { spec. }\end{array}$ & $\begin{array}{c}\Delta \\
(\mathrm{km})\end{array}$ & $\begin{array}{c}O M \\
(\mathrm{~nm} \cdot \mathrm{s})\end{array}$ & $\begin{array}{c}M_{0} \\
(\mathrm{~N} \cdot \mathrm{m})\end{array}$ & $M_{W}$ \\
\hline 12 & 09.07 .2000 & 03 & $\begin{array}{ll}58 & 08.8\end{array}$ & 41.21 & 20.66 & 15 & 2.4 & BIA & 59.7 & 2.1 & $2.10 \mathrm{E}+13$ & 2.8 \\
\hline 13 & 30.03 .1992 & 20 & $\begin{array}{ll}51 & 00.1\end{array}$ & 41.09 & 21.03 & 15 & 2.5 & SKO & 103.8 & 1.3 & $4.90 \mathrm{E}+12$ & 2.4 \\
\hline 14 & 04.09 .1994 & 23 & 5043.0 & 41.09 & 21.23 & 25 & 2.5 & SKO & 99.5 & 1.6 & $9.70 \mathrm{E}+12$ & 2.6 \\
\hline 15 & 15.06 .1998 & 02 & 3346.8 & 41.83 & 21.05 & 20 & 2.5 & BIA & 92.9 & 1.8 & $1.50 \mathrm{E}+13$ & 2.7 \\
\hline 16 & 03.04 .1992 & 14 & 5047.5 & 41.03 & 21.00 & 15 & 2.6 & SKO & 110.9 & 1.7 & $1.30 \mathrm{E}+13$ & 2.7 \\
\hline 17 & 11.06 .1996 & 02 & $\begin{array}{ll}53 & 16.3\end{array}$ & 41.05 & 20.85 & 10 & 2.6 & BIA & 40.0 & 2.4 & $2.80 \mathrm{E}+13$ & 2.9 \\
\hline 18 & 06.11 .1999 & 16 & 4305.7 & 41.81 & 20.66 & 13 & 2.6 & BIA & 103.9 & 2.1 & $3.10 \mathrm{E}+13$ & 2.9 \\
\hline 19 & 21.03 .1993 & 23 & 5547.6 & 41.96 & 20.80 & 13 & 2.8 & SKO & 53.1 & 2.0 & $1.50 \mathrm{E}+13$ & 2.7 \\
\hline 20 & 21.05 .1999 & 03 & 3537.4 & 41.85 & 21.06 & 18 & 2.8 & BIA & 94.9 & 2.0 & $2.40 \mathrm{E}+13$ & 2.9 \\
\hline 21 & 11.05 .1992 & 05 & 3544.9 & 41.72 & 20.95 & 11 & 2.9 & SKO & 49.4 & 2.3 & $2.70 \mathrm{E}+13$ & 2.9 \\
\hline 22 & 15.08 .1992 & 04 & 2106.5 & 40.96 & 20.99 & 19 & 2.9 & SKO & 118.6 & 2.2 & $4.20 \mathrm{E}+13$ & 3.0 \\
\hline 23 & 08.02 .1996 & 14 & 5312.0 & 41.74 & 20.89 & 15 & 2.9 & SKO & 52.4 & 1.9 & $1.20 \mathrm{E}+13$ & 2.7 \\
\hline 24 & 28.11 .1993 & 13 & 1737.3 & 41.14 & 20.90 & 4 & 3.1 & SKO & 102.8 & 2.3 & $4.90 \mathrm{E}+13$ & 3.1 \\
\hline 25 & 01.09 .1994 & 20 & 1118.3 & 41.04 & 20.89 & 11 & 3.1 & SKO & 113.3 & 2.3 & $5.10 \mathrm{E}+13$ & 3.1 \\
\hline 26 & 17. & 13 & $\begin{array}{ll}50 & 00.3\end{array}$ & 41.32 & 20.58 & 18 & 3.2 & BIA & 70.8 & 2.6 & $7.80 \mathrm{E}+13$ & 3.2 \\
\hline 27 & 12.04 .2000 & 07 & 1518.6 & 41.62 & 21.01 & 19 & 3.2 & BIA & 71.7 & 2.3 & $4.00 \mathrm{E}+13$ & 3.0 \\
\hline 28 & 09.07 .2000 & 00 & 0141.3 & 41.20 & 20.62 & 15 & 3.4 & BIA & 62.5 & 3.0 & $1.70 \mathrm{E}+14$ & 3.4 \\
\hline 29 & 29.05 .1992 & 13 & $\begin{array}{ll}45 & 18.7\end{array}$ & 4 & 20.39 & 16 & 3.5 & SKO & 96.6 & 2.8 & $1.50 \mathrm{E}+14$ & 3.4 \\
\hline 30 & 28.07 .1994 & 08 & $05 \quad 15.0$ & 41.36 & 20.50 & 16 & 3.5 & SKO & 103.7 & 2.8 & $1.60 \mathrm{E}+14$ & 3.4 \\
\hline 31 & 01.09 .1994 & 16 & 0233.0 & 41.15 & 21.23 & 25 & 3.5 & SKO & 93.0 & 2.8 & $1.50 \mathrm{E}+14$ & 3.4 \\
\hline 32 & 02.09 & 5 & 3256.7 & 4 & 23 & 16 & 3.5 & SKO & דונ & 3.0 & $2.30 \mathrm{H}$ & .5 \\
\hline 33 & 01.09 .1994 & 19 & 4231.4 & 41.14 & 21.22 & 20 & 3.7 & SKO & 94.2 & 3.2 & $3.70 \mathrm{E}+14$ & 3.7 \\
\hline 34 & 28.09 .1994 & 03 & 2307.1 & 41.86 & 20.58 & 14 & 3.8 & SKO & 72.4 & 3.4 & $5.00 \mathrm{E}+14$ & 3.7 \\
\hline 35 & 22.12 .1996 & 02 & $34 \quad 17.2$ & 40.90 & 21.22 & 17 & 3.8 & SKO & 120.5 & 3.2 & $4.20 \mathrm{E}+14$ & 3.7 \\
\hline 36 & 13.07 .1995 & 12 & 1326.6 & 41.58 & 20.91 & 17 & 4.0 & OHR & 52.9 & 3.8 & $9.40 \mathrm{E}+14$ & .9 \\
\hline 37 & 12.12 .1996 & 15 & $00 \quad 42.1$ & 41.43 & 20.24 & 19 & 4.0 & SKO & 116.6 & 3.3 & $5.20 \mathrm{E}+14$ & 3.8 \\
\hline 38 & 13.08 .1992 & 04 & $52 \quad 29.9$ & 40.98 & 21.02 & 17 & 4.2 & SKO & 115.7 & 3.8 & $1.60 \mathrm{E}+15$ & 4.1 \\
\hline 39 & 30.03 .1992 & 19 & 3201.4 & 41.04 & 20.99 & 19 & 4.8 & SKO & 110.1 & 4.5 & $8.00 \mathrm{E}+15$ & 4.5 \\
\hline 40 & 01.09 .1994 & 16 & 1240.6 & 41.13 & 21.24 & 23 & 5.2 & SKO & 95.0 & 4.9 & $1.90 \mathrm{E}+16$ & 4.8 \\
\hline
\end{tabular}




\section{METHOD OF ANALYSIS}

The theoretical shape $\Omega^{F}$ of the low-frequency level in any particular observed far-field displacement amplitude spectrum of the $S_{g}$ and $L_{g}$ waves was represented by a source term $\Omega_{s}^{F} \equiv \Omega_{0}$ with general shape (1a), wave geometrical spreading term $G$, wave anelastic attenuation term $V$ and term $\left|T_{\text {inst. }}\right|=\left|T_{\text {instr }},(f)\right|$ (see eq. 2) that included the effects of the recording instruments on the recorded displacement amplitudes:

$$
\Omega^{F}=\Omega_{0} \cdot G \cdot V \cdot\left|T_{\text {inst }}\right|
$$

Concerning the relatively short seismic paths included in the analysis, the two Earth's crust layers were homogenized following the model given in Table 1. Further, the treatment of the short-period transverse and surface waves as one type of waves that exhibits transition from spherical (body wave) spreading to cylindrical (surface wave) spreading proposed for a homogenized crust in $[13,30$ and 31] was used here for the upper (granite) crustal layer. Thus the average granite layer phase velocity of $S$ waves from Table $1\left(\beta_{0}=3.45 \mathrm{~km} / \mathrm{s}\right)$ was taken as phase velocity of $S_{g}$ waves and ascribed in the same time to the group velocity of $L_{g}$ waves. The shape of the corresponding divergence coefficient (geometrical spreading factor) was taken as given in [13, 33 and 31],

$$
G=G_{\beta_{0}}\left(R_{H}, R_{H, 0}\right)=\left\{\begin{array}{cl}
\left(R_{H}\right)^{-1}, & R_{H} \leq R_{H, 0}, \\
\left(R_{H, 0} \cdot R_{H}\right)^{-1 / 2}, & R_{H}>R_{H, 0},
\end{array} \quad R_{H, 0}=80 \mathrm{~km} ;\right.
$$

(with our notation). $R_{H, 0}$ is the hypocentral distance at which the transition from spherical to cylindric spreading takes place, the so called Herrman-Kijko distance. Here it was taken $R_{H, 0}=80 \mathrm{~km}$, which is the threshold for $L_{g}$ phase on the territory of the Republic of Macedonia, found also in our data, as mentioned above.

A frequency independent quality factor $(Q)$ in the anelastic attenuation $V$ of the $S_{g}$ and $L_{g}$ phases was used here, according to the previously proved weak dependence of this factor on frequency in frequency bands such as those

Прилози, Одд. мат. тех. науки, XXVII-XXVIII, 1-2 (2006-2007), стр. 93-115 
included in the data analysed here [e.g., 32]. On the other hand, for the analysed seismic paths that were spread within the Vardar and West Macedonia seismic zones, what was mostly the case, we accepted the dependence of the $Q$ factor on source-receiver azimuthal distance that had been proved for both zones in the investigation [33]. The average frequency independent $Q$ factors for $S$ waves obtained in [33] for three main directions were ascribed here to $S_{g}$ and $L_{g}$ waves along the same directions (Fig. 1):

$$
\begin{aligned}
& \mathrm{SKO} \leftrightarrow \mathrm{VAY} \text {, along the Vardar seismic - direction } l_{1} \text { : } \\
& \qquad Q_{\beta_{0} l_{1}}=86,
\end{aligned}
$$

$\mathrm{OHR} \leftrightarrow \mathrm{SKO}$, along the West Macedonia seismic zone - direction $l_{2}$ :

$$
Q_{\beta_{0}, l_{2}}=56
$$

$$
\begin{gathered}
\mathrm{OHR} \leftrightarrow \mathrm{VAY}, \text { across both zones }- \text { direction } l_{3}: \\
\qquad Q_{\beta_{0}, l_{3}}=68 .
\end{gathered}
$$

Only three of the analysed seismic paths crossed the East Macedonia seismic zone, nearly with their entire lengths (Table 2, Vardar seismic zone, events No. 1, 2 and 4, station KPJ used in the analysis). The East Macedonia seismic zone has not been previously studied for the $Q$ factor, and we chose here the mean value of the above three values for all directions in that zone (see also Fig. 1):

East Macedonia seismic zone, all directions $-l_{4}$ :

$$
Q_{\beta_{0}, l_{4}}=70 \text {. }
$$

Since all the seismological stations on the territory of the Republic of Macedonia are installed at consolidated rocks, no site effects were included in the final anelastic attenuation $V$, and it was taken as:

$$
V=V_{\beta_{0}}^{1}\left(R_{H}, f\right)=\exp \left(-\frac{\pi \cdot f \cdot R_{H}}{\beta_{0} \cdot Q_{\beta_{0}, l_{i}}}\right), \quad i=1,2,3,4
$$


For a seismic path within the Vardar and West Macedonia seismic zones, this relation was used with giving to $Q_{\beta_{0}, l_{i}}$ the value correspondent to the direction $l_{i}$ from (5) which is the closest in orientation to the seismic path. For the three seismic paths crossing the East Macedonia seismic zone nearly with their entire lengths, mentioned above, the eq. (7) was used with $Q_{\beta_{0}, l_{4}}=70$.

The source term $\Omega_{0}$ in (3) was chosen, as said above, after the Brune dislocation model [26-27]. The model uses a static circular fault surface that is equivalent $\left(\Sigma_{L, e q}\right)$ to the real final fault surface and for $S$ waves gives:

$$
\Omega_{0}=\frac{\left\langle f_{\vartheta \varphi}^{F}\right\rangle \cdot M_{0}}{4 \pi \cdot \rho_{0} \cdot \beta_{0}^{3}}=\frac{0.6324 \cdot M_{0}}{4 \pi \cdot \rho_{0} \cdot \beta_{0}^{3}} .
$$

$\left\langle f_{\vartheta \varphi}^{F}\right\rangle=0,6324$ is the RMS for the $S$ wave radiation pattern, which we here ascribed to the RMS-s of the radiation patterns of analysed $S_{g}$ and $L_{g}$ waves. Further, $\rho_{0}$ and $\beta_{0}$ are respectively the density and the $S$ wave phase velocity in the vicinity of the real fault, which we took as constants throughout the granite crustal layer, with values from Table $1, \rho_{0}=2.82 \cdot 10^{3} \mathrm{~kg} / \mathrm{m}^{3}$ and $\beta_{0}=3.45 \mathrm{~km} / \mathrm{s}$, ascribing $\beta_{0}=3.45 \mathrm{~km} / \mathrm{s}$ to the $S_{g}$ wave phase velocity and $L_{g}$ wave group velocity.

With the above assumptions, the theoretical low-frequency level (3) becomes

$$
\begin{aligned}
& \Omega^{F}=\Omega^{F}\left(R_{H}, f\right)_{f \rightarrow 0}=\Omega_{0} \cdot G_{\beta_{0}}\left(R_{H}, R_{H, 0}\right) \cdot V_{\beta_{0}}\left(R_{H}, f\right) \cdot\left|T_{\text {instr }}(f)\right|= \\
& \left.=\Omega_{0} \cdot \exp \left(-\frac{\pi \cdot f \cdot R_{H}}{\beta_{0} \cdot Q_{\beta_{0}, l_{i}}}\right) \cdot \mid T_{\text {instr. } .(f)}\right) \cdot \begin{cases}\left(R_{H}\right)^{-1}, & R_{H} \leq R_{H, 0}=80 \mathrm{~km} \\
\left(\mathrm{R}_{\mathrm{H}, 0} \cdot R_{H}\right), & R_{H}>R_{H, 0}=80 \mathrm{~km}\end{cases}
\end{aligned}
$$

where $Q_{\beta_{0}, l_{i}}$ is evaluated following relations (5) and (6) in the way described above, and $\Omega_{0}$ and $\left|T_{\text {instr }}(f)\right|$ are given respectively by eqs. (8) and (2).

The time window for the final amplitude spectral analysis of the selected data in SEISAN 7.2 was chosen to include the entire duration of the $S_{g}$ 
or $L_{g}$ phase or the entire durations of both phases, the latter one being used in cases when the $L_{g}$ phase was not quite well developed on the record (Fig. 2a). Thus, the time window lengths included in the final amplitude spectral analysis were between few and 15 seconds.

Log-amplitude spectra of the selected seismic traces were obtained in SEISAN 7.2. Those spectra were corrected there at first for $V_{\beta_{0}}^{l}$, following eq. (7), and, second, for $\left|T_{i n s t r}(f)\right|$, following eq. (2), with parameters of the used instruments and filters as listed in the original technical documentation of the producers. Thus it follows from eq. (9) that the low-frequency levels of those twice corrected log-amplitude spectra, read in SEISAN 7.2 as OM (Fig. 2b), are given by

$$
O M=\lg \left(\Omega_{0} \cdot G_{\beta_{0}}\right)
$$

The read $O M$ values were used further to estimate the seismic moments of the earthquakes using eq. (8), with $G_{\beta_{0}}$ given by eq. (4),

$$
\begin{aligned}
& M_{0}=\frac{10^{O M}}{0.6324} \cdot 4 \pi \cdot \rho_{0} \cdot \beta_{0}^{3} \cdot R_{H}, \text { for } R_{H} \leq R_{H, 0}=80 \mathrm{~km}, \\
& M_{0}=\frac{10^{O M}}{0.6324} \cdot 4 \pi \cdot \rho_{0} \cdot \beta_{0}^{3} \cdot R_{H, 0}^{1 / 2} \cdot R_{H}^{1 / 2}, \text { for } R_{H} \leq R_{H, 0}=80 \mathrm{~km},
\end{aligned}
$$

where the values $\rho_{0}=2.82 \cdot 10^{3} \mathrm{~kg} / \mathrm{m}^{3}$ and $\beta_{0}=3.45 \mathrm{~km} / \mathrm{s}$ from Table 1 were used.

Moment magnitudes $M_{W}$ of the earthquakes were calculated using the Kanamori formula from [8],

$$
M_{W}=\frac{\lg M_{0}}{1.5}-6.06, \quad M_{0} \text { in } \mathrm{N} \cdot \mathrm{m} .
$$




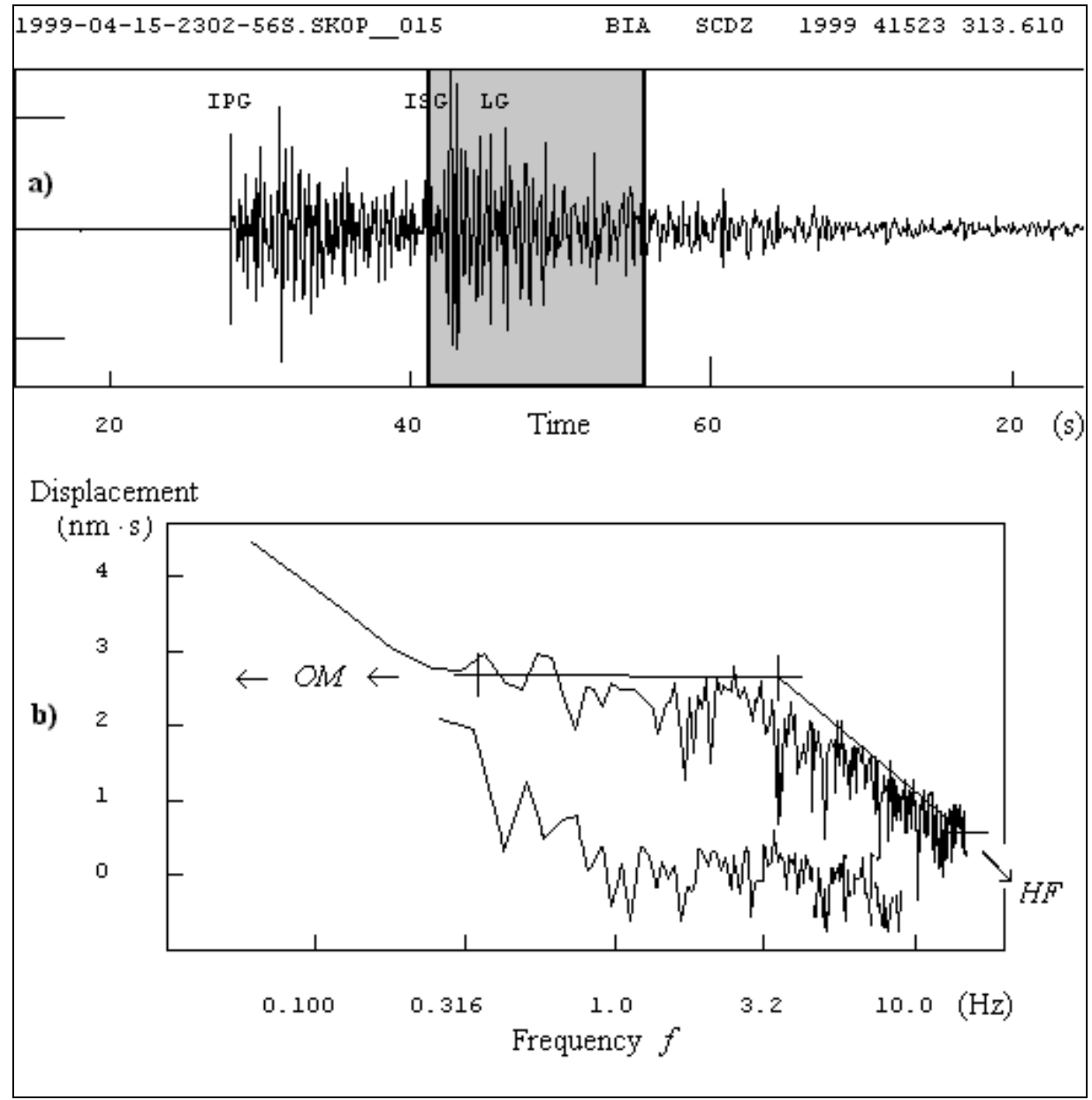

Fig. 2. a) The digital record of the $M_{L}=3.6$ Skopje earthquake of April 6, 1999, 23 h 02 min UTC (Table 2, Vardar seismic zone, event No.31), on the vertical component of the short-period electromagnetic SS-1 seismometer at the station in Bitola (BIA), for which the epicentral distance is $\Delta=103.9 \mathrm{~km}$. The onsets of the seismic phases $P_{g}, S_{g}$ and $L_{g}$ are shown too. b) The obtained in SEISAN 7.2 software log-amplitude spectrum of the $S_{g}$ and $L_{g}$ phases (shaded part of the trace in the upper part of the figure), after the corrections of the effects of the instruments and anelastic attenuation. The straight lines present the low-frequency and high-frequency asymptotes ( $O M$ and $H F$, respectively), with their intersection point as a corner frequency.

The lower part in the plot presents the log-amplitude spectrum of the noise. 


\section{RESULTS}

The obtained seismic moments and moment magnitudes are given in Table 2. For the Vardar seismic zone, with the included local magnitudes $M_{L}=1.5-5.2$, the seismic moments $M_{0}$ have values between $0.97 \cdot 10^{12}$ and $3.00 \cdot 10^{16} \mathrm{~N} \cdot \mathrm{m}$, and the moment magnitudes $M_{W}$ have values between 1.9 and 4.9. For the West Macedonia seismic zone, with the included local magnitudes $M_{L}=1.4-5.2$, the obtained $M_{0}$ have values between $0.89 \cdot 10^{12}$ and $1.9 \cdot 10^{16} \mathrm{~N} \cdot \mathrm{m}$, and $M_{W}$ have values between 1.9 and 4.8 .

The results provided linear $\lg M_{0}=M_{L}$ correlations (Fig. 3):

- for the Vardar seismic zone,

$$
\begin{gathered}
\lg M_{0}=(1.11 \pm 0.03) \cdot M_{L}+(10.28 \pm 0.09), \\
1.5<M_{L}<5.2,\left(M_{0} \text { in N.m }\right),
\end{gathered}
$$

with correlation coefficient $r=0.9853 \pm 0.0281$;

- for the West Macedonia seismic zone,

$$
\begin{gathered}
\lg M_{0}=(1.14 \pm 0.04) \cdot M_{L}+(10.27 \pm 0.12), \\
1.4<M_{L}<5.2,\left(M_{0} \text { in } \mathrm{N} \cdot \mathrm{m}\right),
\end{gathered}
$$

with correlation coefficient $r=0.9785 \pm 0.0335$. The above correlations are in a very good agreement with those obtained in [15, 20 and 22].

The results also provided linear $M_{W}-M_{L}$ correlations (Fig. 4):

- for the Vardar seismic zone,

$$
M_{W}=(0.75 \pm 0.02) \cdot M_{L}+(0.77 \pm 0.06), 1.5<M_{L}<5.2,
$$

with correlation coefficient $r=0.9849 \pm 0.0285$;

- for the West Macedonia seismic zone,

$$
M_{W}=(0.76 \pm 0.03) \cdot M_{L}+(0.78 \pm 0.08), 1.4<M_{L}<5.2,
$$

with correlation coefficient $r=0.9788 \pm 0.0332$. 

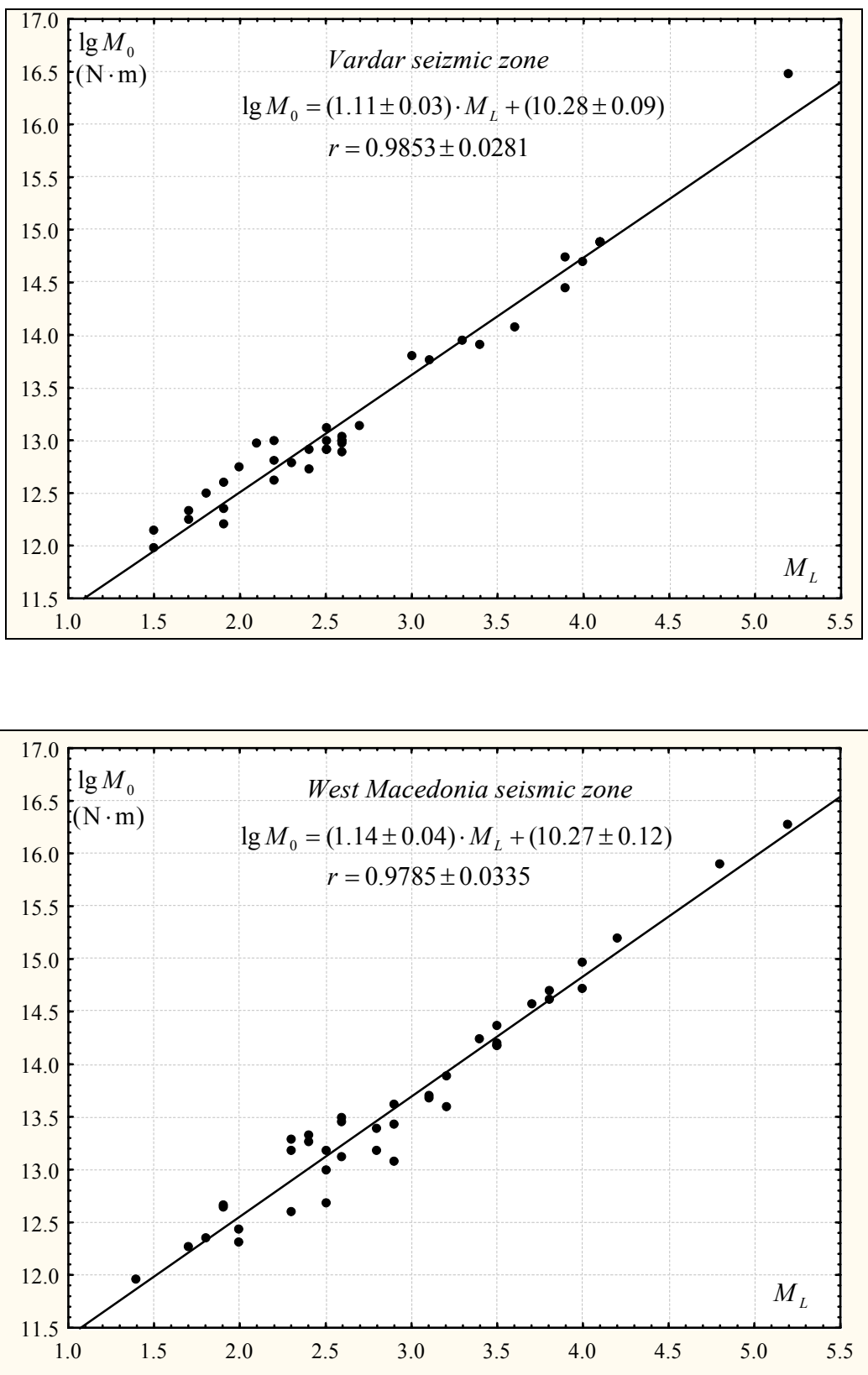

Fig. 3. Plots of logarithm of seismic moment $M_{0}$ versus local magnitude $M_{L}$ for the Vardar and West Macedonia seismic zones. Linear regressions that are the best fits to, the data are given, too, with corresponding correlation coefficients $r$ 

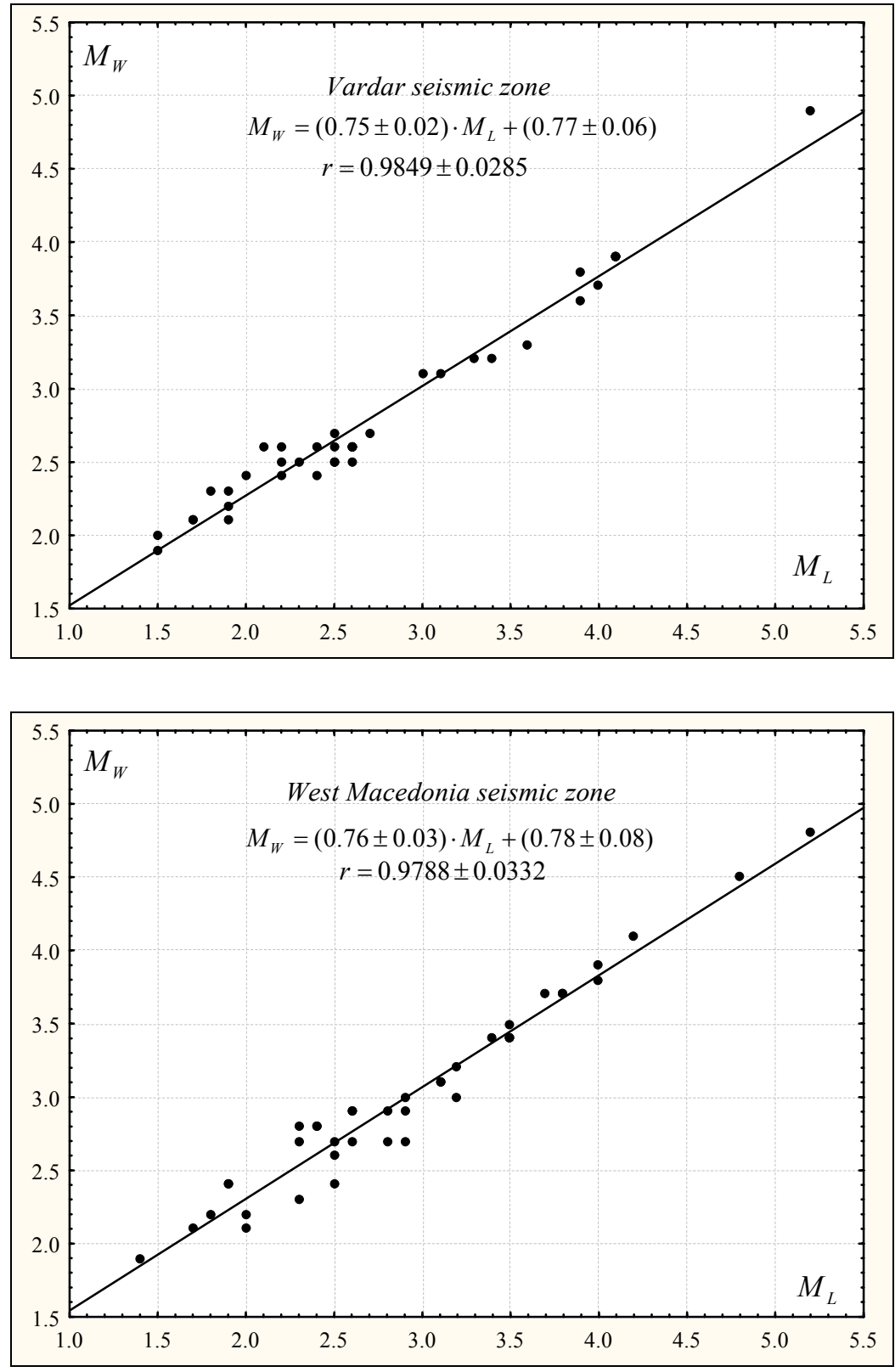

Fig. 4. Plots of calculated moment magnitudes $M_{W}$ versus local magnitudes $M_{L}$ for the Vardar and West Macedonia seismic zones. Linear regressions that are the best fits to the data are given, too, with corresponding correlation coefficients $r$ 
The correlations (13) - (16) are the first of the kind obtained for seismic zones on the territory of the Republic of Macedonia. As empirical ones, they statistically include the specifics of the crust structure under that territory, and thus can be very useful in seismic regionalization and assessment of seismic hazard on that territory. They can also ensure quick evaluation of $M_{0}$ and $M_{W}$ for any earthquake only on the basis of its local magnitude $M_{L}$. With $M_{0}$ determined, other source parameters can be evaluated using eq. (1b).

However, besides the high correlation coefficient in those correlations, the $M_{0}$ and $M_{W}$ values for the $M_{L}=5.2$ Bitola and Gjilane earthquakes in the $\left(M_{L}, \lg M_{0}\right)$ and $\left(M_{L}, M_{W}\right)$ plots in Figs. 3-4 decline from the trends of the $M_{0}$ and $M_{W}$ values for the other earthquakes. It seems that if those two earthquakes were excluded, the $\lg M_{0}-M_{L}$ and $M_{W}-M_{L}$ correlations would be somehow different.

Although more data with $M_{L}>5.2$ are needed to strictly confirm it, the above conclusion appoints to a differentiation between classes of small and middle-sized earthquakes at $M_{L}=5.2$ in both zones. Earthquakes with $M_{L}>5.2$ should be put in the class of middle-sized earthquakes. They should be taken as events that are not similar to events with $M_{L}<5.2$ and should be studied separately. It might be also the case that the Brune dislocation model shows a certain non-adequacy for the sources of the $M_{L}>5.2$ earthquakes. The effects of the dislocation moving in a finite time interval and into dominant directions might be non-negligible for those sources, and thus the static circular fault surface of the Brune dislocation model might become a non-appropriate approximation.

From the other side, slight inflexions in the trends of the $M_{0}$ and $M_{W}$ values can be noticed in the $\left(M_{L}, \lg M_{0}\right)$ and $\left(M_{L}, M_{W}\right)$ plots in Figs. 3-4, at $M_{0} \approx 6 \cdot 10^{13} \mathrm{~N} \cdot \mathrm{m}$ or $M_{L} \approx 3.0$, for the Vardar seismic zone, and at $M_{0} \approx 1.5 \cdot 10^{14} \mathrm{~N} \cdot \mathrm{m}$ or $M_{L} \approx 3.5$, for the West Macedonia seismic zone. This points to a possible hidden change in the scaling law of small earthquakes $\left(M_{L} \approx 5.2\right)$ at those values of $M_{0}$ and $M_{L}$. The latter one might be due to a breakdown or a change of conditions of self-similarity of those earthquakes. The lower values for which this change is suggested for the Vardar seismic zone might mean that this zone is geologically and tectonically heterogeneous at a lower dimension level than the West Macedonia seismic zone. The more expressed compactness of the latter zone, result of which would be the higher threshold $\left(M_{0} \approx 1.5 \cdot 10^{14} \mathrm{~N} \cdot \mathrm{m}\right.$ or $\left.M_{L} \approx 3.5\right)$ for the change in the scaling law of the small earthquakes, was very often connected with the old age of the crust in the zone [e.g. 23]. 
However, as seen further from plots in Figs. 3-4, more data with $M_{L}$ values in the intervals $4.0<M_{L}<5.2$ and $3.0 \leq M_{L} \leq 3.5$ are needed for both zones, and specially for the Vardar seismic zone, to confirm strictly the change and to properly correlate $M_{0}$ and $M_{L}$ or $M_{W}$ and $M_{L}$ separately in the $M_{L}$ intervals below and above the change.

\section{CONCLUSIONS}

The inversion of amplitude spectra of vertical components of $S_{g}$ and $L_{g}$ seismic waves on the Brune dislocation model was very successful in providing relations of seismic moment $M_{0}$ and earthquake moment magnitude $M_{W}$ to earthquake local magnitude $M_{L}$ for the Vardar and West Macedonia seismic zones.

The inversion also appointed to a possible differentiation between classes of small and middle-sized earthquakes on the territory of the Republic of Macedonia at $M_{L}=5.2$. It suggested further a change in the scaling law of small earthquakes $\left(M_{L}<5.2\right)$ at $M_{0} \approx 6 \cdot 10^{13} \mathrm{~N} \cdot \mathrm{m}$ or $M_{L} \approx 3.0$, for the Vardar seismic zone, and at $M_{0} \approx 1.5 \cdot 10^{14} \mathrm{~N} \cdot \mathrm{m}$ or $M_{L} \approx 3.5$, for the West Macedonia seismic zone, or at $M_{0} \approx 6 \cdot 10^{13}-1.5 \cdot 10^{14} \mathrm{~N} \cdot \mathrm{m}$ or $M_{L} \approx 3.0-3.5$ when both zones are taken together.

All this gives a good basis for further detailed studies of seismic sources on the territory of the Republic of Macedonia.

The results also appointed to more irregular geological and tectonic conditions of the Vardar seismic zone in comparison with those of the West Macedonia zone. This is quite in accordance with the results from previous geological and tectonic investigations and gives a basis to properly connect the investigations of that kind with the seismological ones.

\section{REFERENCES}

[1] K. Aki, P. G. Richards, Quantitive Seismology. Theory and Methods. Vol. I, II. W. H. Freeman and Company, San Francisco, 1980.

[2] К. Касахара, Механика землейрясении́. Мир, Москва. (Russian translation of the original published in English in 1981), 1985.

[3] Б. В. Костров, Механика очага тектонического землетрясения. Наука, Москва, 1975.

Contributions, Sec. Math. Tech. Sci., XXVII-XXVIII, 1-2 (2006-2007), pp. 93-115 
[4] A. Ben-Menahem, S. J. Singh, Seismic Sources and Waves. Springer-Verlag, New York, 1981.

[5] K. Aki, Generation and propagation of $G$ waves from the Niigata earthquake of June 16, 1964. Part 2. Estimation of earthquake moment, released energy and stress-strain drop from the $\mathrm{G}$ wave spectrum, Bulletin of the Earthquake Research Institute, 44, (Part 1) (1966) 73-88.

[6] K. Aki, Earthquake mechanism. Tectonophysics, 13 (1972) 423-446.

[7] K. Aki, Scaling law of earthquake source time-function, Geophysical Journal of the Royal Astronomical Society, 31, (1972) 3-25.

[8] H. Kanamori, The energy release in great earthquakes, Journal of Geophysical Research, 82 (1977) 2981-2987.

[9] H. Kanamori, D. L. Anderson, Theoretical basis of some empirical relations in seismology, Bulletin of the Seismological Society of America, 65 (1975) 10731095.

[10] A. Ben-Menahem, S. W. Smith, Teng Ta-Liang, A procedure for source studies from spectrums of long-period seismic body waves, Bulletin of the Seismological Society of America, 55 (1965) 203-235.

[11] J. N. Brune, C. Y. King, Excitation of mantle Rayleigh waves of period $100 \mathrm{sec}-$ onds as a function of magnitude, Bulletin of the Seismological Society of America, Vol. 57 (1967) 1355-1365.

[12] W. Thatcher, T. C. Hanks, Source parameters of southern California earthquakes, Journal of Geophysical Research, 78 (1973) 8547-8576.

[13] R. L. Street, R. B. Herrmann, O. W. Nuttli, Spectral characteristics of the $L_{g}$ wave generated by Central United States earthquakes, Geophysical Journal of the Royal Astronomical Society, 41 (1975) 51-63.

[14] R. Geller, Scaling relations for earthquake source parameters and magnitudes, Bulletin of the Geological Society of America, 66 (1976) 1501-1523.

[15] W. A. Peppin, C. G. Bufe, Induced versus natural earthquakes: search for a seismic discriminant, Bulletin of the Seismological Society of America, 70 (1980) 269-281.

[16] H. S. Hasegawa, $L_{g}$ spectra of local earthquakes recorded by the Eastern Canada Telemetred Network and spectral scaling, Bulletin of the Seismological Society of America, 73 (1983) 1041-1061.

[17] T. C. Hanks, D. M. Boore, Moment-magnitude relations in theory and practice, Journal of Geophysical Research, 89 (1984) 6229-6235-784.

[18] W. H. Bacun, Seismic moments, local magnitudes and coda-duration magnitudes for earthquakes in Central California, Bulletin of the Seismological Society of America, 74 (1984) 439-458.

[19] J. Boatwright, Regional propagation characteristics and source parameters of earthquakes in northeastern North America, Bulletin of the Seismological Society of America, 84 (1994) 1-15.

Прилози, Одд. мат. тех. науки, XXVII-XXVIII, 1-2 (2006-2007), стр. 93-115 
[20] L. B. Kvamme, R. A. Hansen, H. Bungum, Seismic-source and wave-propagation effects of $L_{g}$ waves in Scandinavia, Geophysical Journal International, 120, (1995) 525-536.

[21] J. Shi, W. Kim, P. G. Richards, The corner frequencies and stress drops of intraplate earthquakes in the northeastern United States, Bulletin of the Seismological Society of America, 88 (1998) 531-542.

[22] E. M. Abdelrahman, M. M. Dessokey, H. M. Hussein, M. F. Abdelwahed, Estimation of seismic moments from local magnitudes and coda durations for the Cairo earthquake aftershocks recorded at Kottamyia (KEG) broadband station, Annals of Geophysics/Annali di Geofisica, 46 (2003) 1209-1216.

[23] M. Arsovski, Tectonics of Macedonia. Rudarsko-Geološki fakultet, Štip, 1997 (In Macedonian.)

[24] D. Hadžievski, Seismicity of the Territory of the S. R. Macedonia. Seizmološka opservatorija na Univerzitetot "Kiril i Metodij", Skopje. (1976) (In Macedonian),

[25] Qj. Jordanovski, L. Pekevski, V. Čejkovska, D. Černih, B. Hristovski, N. Vasilevski. Main Characteristics of the Seismicity of the Territory of the Republic of Macedonia. Univerzitet "Sv. Kiril i Metodij", Prirodno-matematički fakultet, Seizmološka opservatorija, Skopje. (1998) (In Macedonian).

[26] J. N. Brune, Tectonic stress and spectra of seismic shear waves from Earthquakes, Journal of Geophysical Research, 75 (1970) 4997-5009.

[27] J. N. Brune, Correction, Journal of Geophysical Research, 76 (1971) 5002.

[28] UNDP/UNESCO: Tables des temps de propagation des ondes séismiques (Hodochrones) pour la région des Balkans. Manuel d'Utilisation. Strasbourg, (1972) $55 \mathrm{p}$.

[29] J Havskov,. L. Ottemöller, Seisan: The Earthquake Analysis Software for Windows, Solaris and Linux, Version 7.2. Institute of Solid Earth Physics, University of Bergen, Bergen, Norway (2001).

[30] R. B. Herrmann, A. Kijko, Modelling some empirical vertical component $L_{g}$, Bulletin of the Seismological Society of America, 73 (1983) 157-171.

[31] R. B. Herrmann, An extension of random vibration theory estimates of strong ground motion to large distances, Bulletin of the Seismological Society of America, 75 (1985). 1447-1453.

[32] S. K. Singh,, R. J. Apsel, J. Fried, J. N. Brune, Spectral Attenuation of SH waves along Imperial Fault, Bulletin of the Seismological Society of America, 72, (1982) 2003-2016.

[33] L. Pekevski, Propagation of Seismic Waves of Local and Regional Earthquakes. Univerzitet "Sv. Kiril i Metodij", Prirodno-matematički fakultet, Seizmološka opservatorija, Skopje. A doctorial thesis, (1999) (In Macedonian). 
Р е $з$ и м е

\section{ЕМПИРИСКИ РЕЛАЦИИ НА СЕИЗМИЧКИОТ МОМЕНТ \\ И ЗЕМЈОТРЕСНАТА МОМЕНТНА МАГНИТУДА \\ СО ЗЕМЈОТРЕСНАТА ЛОКАЛНА МАГНИТУДА ЗА ВАРДАРСКАТА И ЗАПАДНО-МАКЕДОНСКАТА СЕИЗМОГЕНА ЗОНА}

Сеизмичките моменти $\left(M_{0}\right)$ на 79 земјотреси, случени во периодот 1992-2002 година во Вардарската и Западно-македонската сеизмогена зона од територијата на Република Македонија и околните подрачја, добиени се со инверзија на амплитудните спектри на вертикалните компоненти на краткопериодичните трансверзални $S_{g}$ и $L_{g}$ површински земјотресни бранови, регистрирани дигитално на електромагнетските краткопериодични $S S-1$ и широкопојасни $W R-1$ Кинеметриксови сеизмометри во станиците во Скопје (SKO), Охрид (OHR), Валандово (VAY), Битола (BIA) и Крива Паланка (КРЈ). Инверзијата е изведена со помош на Бруновиот дислокациски модел на земјотресното жариште и соодветен модел на средината. Податоците вклучија локални магнитуди $\left(M_{L}\right)$ на земјотресите помеѓу 1,5 и 5,2, за Вардарската, и помеѓу 1,4 и 5,2, за Западно-македонската сеизмогена зона. Моментните магнитуди $\left(M_{W}\right)$ на земјотресите се одредувани со формулата на Канамори. Добиени се емпириски релации $M_{0}-M_{L}$, први од тој вид за сеизмогени зони од територијата на Република Македонија. Резултатите укажуваат и на можноста на разликување на класи на слаби и средно силни земјотреси веќе кај $M_{L}=5,2$, како и на веројатна промена на мерниот закон на слабите земјотресите за $M_{L} \approx 3,0-3,5$ односно $M_{0} \approx 6 \cdot 10^{13}-1,5 \cdot 10^{14} \mathrm{~N} \cdot \mathrm{m}$.

Клучни зборови: параметри на земјотресно жариште; сеизмички момент; земјотресна моментна магнитуда; емпириски релации

Address:

Vera Čejkovska

Seismological Observatory, Faculty of Natural Sciences and Mathematics,

SS. Cyril and Methodius University, Skopje

P.O. Box 422, MK-1001 Skopje, Republic of Macedonia

Veracejkovska@yahoo.com

Received: 16. XI 2006

Accepted: 8. III 2007

Прилози, Одд. мат. тех. науки, XXVII-XXVIII, 1-2 (2006-2007), стр. 93-115 